\title{
DISCONTINUITY OF LINGKAGE CIRCULATION STRUCTURE WITHIN THE AREA OF KERATON KASEPUHAN CIREBON CASE STUDY: KERATON KASEPUHAN COMPLEX; MANDALANGEN KAMPONG
}

\author{
${ }^{1}$ Bregas Vikri Prayuko. ${ }^{2}$ Dr. Ir. Y. Karyadi Kusliansjah, M.T. \\ ${ }^{1}$ Student in the Bachelor's (S-1) Study Program in Architecture at \\ Parahyangan Catholic University \\ ${ }^{2}$ Senior lecturer in the Bachelor's (S-1) Study Program in Architecture at \\ Parahyangan Catholic University
}

\begin{abstract}
The Kasepuhan Cirebon Palace is a living and standing city monument that acts as a city artifact. The existence of the palace itself has been established since the fourteenth century as the kingdom's capital. A castle cannot stand on its own as a city monument, hence the existence of urban function elements such as; Housing, Circulation, and Fixed Activities as described by Aldo Rossi in The Architecture of the city, 1982. Within the complex of this palace, there are two main areas surrounded by a fortress wall, namely the Keraton complex as the dwelling for Sultan Sepuh (the King), and the Kampung Mandalangen Complex as the dwelling for abdi dalem (servants, subordinates) and royal relatives. The method used in this research is descriptive-quantitative with Continuity, Connectivity, and Depth analysis (Marshall, Stephen, Streets \& Patterns. 2003) to discover Street Types in the form of stem, spine and cross-connector within the area. After discovering the Backbone of the complex, (the writer) then descriptively provides the Ragaan (visual/description) in the form of the orientation of the complexes towards one another. In time, many changes have happened to this area. Special mention must be made of the phenomenon of open/close permeability to the Keraton Kasepuhan Cirebon (between complexes and outside of the complex), along with the phenomenon of spatial non-physical aspects (palatial policy and citizens' behavior) that affects the spatial physical element. Both phenomena have created a shift in the Circulation link structure of both complexes, as well as relations between both complexes.
\end{abstract}

Keywords: Keraton Kasepuhan Cirebon, Relation, Circulation Link Structure, Backbone, DisContinuity.

\section{DISKONTINUITAS STRUKTUR TAUTAN SIRKULASI DALAM KAWASAN KERATON KASEPUHAN CIREBON STUDI KASUS: KOMPLEK KERATON KASEPUHAN; KAMPUNG MANDALANGEN}

\author{
${ }^{1}$ Bregas Vikri Prayuko. ${ }^{2}$ Dr. Ir. Y. Karyadi Kusliansjah, M.T. \\ ${ }^{1}$ Mahasiswa S1 Jurusan Arsitektur Universitas Katolik Parahyangan \\ 2 Dosen Pembimbing S1 Program Studi Arsitektur Universitas Katolik Parahyangan
}

\begin{abstract}
Abstrak- Keraton Kasepuhan Cirebon adalah suatu monumen kota yang masih hidup dan berdiri sebagai suatu city artefact. Keberadaan Keraton Kasepuhan Cirebon sendiri telah ada sejak abad ke-14 sebagai pusat kerajaan. Keraton ini tidak bisa berdiri sendiri sebagai suatu monumen kota, karena itu hadir pula elemen-elemen urban function yang ada, yaitu Housing, Circulation, dan Fixed Activities (Rossi, Aldo. The Architecture of the city. 1982). Pada lingkup

${ }^{1}$ Corresponding Author: GagasPrayuko@rocketmail.com
\end{abstract}


Keraton Kasepuham Cirebon, terdapat dua kawasan utama yang dikelilingi oleh tembok benteng, yaitu Kompek Keraton sebagai tempat tinggal Sultan Sepuh, dan Komplek Kampung Mandalangen sebagai permukiman abdi dalem dan kerabat keraton. Metode yang digunakan pada penelitian ini adalah kuantitatif-deskriptif dengan melakukan analisa Continuity, Connectivity, dan Depth (Marshall, Stephen. Streets \& Patterns. 2003) untuk menemukan Street Types yang berupa stem, spine, dan cross-connector pada kawasan. Setelah mendapatkan Backbone komplek, lalu secara deskriptif memberikan ragaan berupa orientasi komplek satu-sama-lain. Seiring berjalannya waktu, banyak perubahan yang terjadi pada kawasan ini. Terjadi fenomena terbuka / tertutupnya permeabillitas pada Keraton Kasepuhan Cirebon (antar komplek dan keluar komplek), fenomena non-fisik spasial (kebijakan keraton dan perilaku warga) yang berpengaruh secara fisik spasial. Kedua fenomena itu menjadikan adanya perubahan tautan sirkulasi pada masing-masing komplek, dan juga relasi diantara kedua komplek tersebut.

Kata-kata kunci: Keraton Kasepuhan Cirebon, Relasi, Struktur Tautan Sirkulasi, Backbone, Diskontinuitas

\section{PENDAHULUAN}

Cirebon sebagai kota dengan nilai historis yang tinggi. Dengan adanya catatan sejarah sejak awal abad 14. Menurut masuskrip Purwaka Caruban Negeri, dahulu cirebon berdiri sebagai sebuah kampung nelayan bernama Muara Jati. Pada saat itu sudah terdapat banyak kapal asing yang berlabuh untuk melakukan perdagangan pada kampung tersebut. Dari pelabuhan tersebut, berkembanglah budaya islam yang menyebar melalui pedagangpedagang dari timur tengah.

Keraton Kasepuhan Cirebon, terletak tepat pada bagian utara Sungai Kriyan, berdiri sebagai artefak kota Cirebon yang penting. Berdiri sebagai salah satu bangunan paling tua di Cirebon, Keraton ini juga sebagai satu-satunya keraton yang masih memegang status monarki yang masih berlanjut secara garis keturunan. Signifikansi dari monumen kota ini juga tidak terbayangkan jika melihat dampak sosial, ekonomi, dan budaya yang ditimbulkan dari kehadiran Keraton Kasepuhan Cirebon ini.

Berdiri sebagai sebuah kawasan, Keraton Kasepuhan Cirebon memiliki elemenelemen Keraton, antara lain seperti Alun-Alun, Mesjid, dan Keraton itu sendiri. Menurut fungsinya, Keraton Kasepuhan Cirebon memiliki dua komplek didalamnya, yaitu adalah Komplek Keraton yang menjadi pusat pemerintahan, budaya, dan tempat tinggal Sultan Sepuh, dan Kampung Mandalangen yang berfungsi sebagai lingkup permukiman bagi selir, kerabat dan abdi dalem Keraton Kasepuhan Cirebon.

Pada Keraton Kasepuhan Cirebon, kedua komplek tersebut terbentuk dari kota bertembok (walled city) dengan adanya tembok yang mengeliling seluruh keraton, menjadikan keraton tersebut sebagai suatu benteng (fortress). Terdapat juga suatu tembok yang membatasi antar kawasan pada Keraton Kasepuhan Cirebon. Dalam keberadaanya, tembok tersebut telah ada sejak tahun 1473. Data tersebut didapatkan dari hasil wawancara dengan juru kunci Dalem Agung.

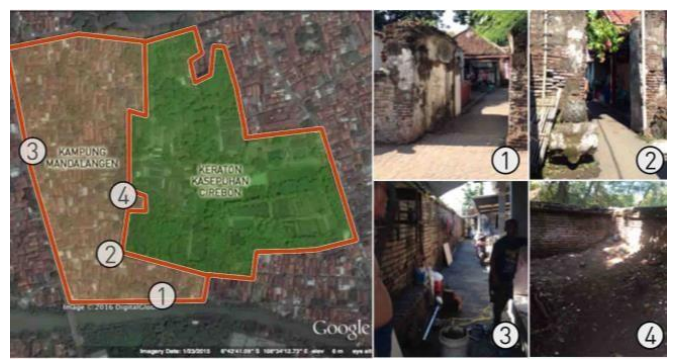


Figur 1. Tembok Benteng pada Keraton Kasepuhan Cirebon (Sumber: Citra Google Earth 2016 diolah pribadi, Dokumentasi Pribadi)

Tentu dalam keberadaan Kampung Mandalangen dan Keraton Kasepuhan Cirebon, kedua komplek tersebut saling "berdialog" secara aktivitas yang melengkapi satu sama lain; meskipun dengan adanya tembok pembatas ruang fisik spasial diantara kedua komplek tersebut. Terlepas dari hal fisik yang ada pada kawasan ini, terdapat fakta non-fisik spasial yang berpengaruh pada kedua komplek ini, diantaranya adalah kebijakan keraton, dan perilaku warga yang berpengaruh pada tatanan fisik pada kawasan ini.

Yang dimaksud dengan fakta non-fisik adalah, kondisi saat ini bahwa kampung Mandalangen, yang pada saat dahulu hanya boleh dihuni oleh Abdi Dalem keraton, sekarang sudah bisa dihuni oleh non-Abdi Dalem, atas permohonan calon penduduk tersebut dan izin Sultan Sepuh. Begitu pula dengan izin permohonanuntuk membongkar tembok yang mengelilngi keraton dengan tujuan untuk membuka akses sirkulasi, juga dengan izin dari Sultan Sepuh.

\subsection{ISU PENELITIAN}

\subsubsection{FENOMENA TERBUKA/TERTUTUPNYA TITIK TEMBUS (PERMEABILITAS), DAN RELASI PADA KERATON KASEPUHAN CIREBON}

Dalam relasi aktivitas yang ada pada kedua kawasan tersebut, tentu dibutuhkan "titik tembus" untuk jalur manusia pada kedua kawasan tersebut. Permeabilitas hadir sebagai titik tembus tetap bagi Kawasan Keraton Kasepuhan Cirebon. Karena adanya tembok benteng yang berupa monumen sejarah, titik-titik tembus yang ada tentunya memiliki signifikansi tersendiri terkait letak dan keberadaannya secara hierarki ataupun kepentingan bagi kedua komplek tersebut.

\subsubsection{FENOMENA PERKEMBANGAN KOTA SECARA FISIK-SPASIAL DAN NON- FISIK-SPASIAL PADA KERATON KASEPUHAN CIREBON}

Dalam lingkup batasan Keraton Kasepuhan Cirebon, segala pembangunan yang ada harus dengan izin dari Sultan Sepuh. Begitu pula dengan prilaku masyarakat yang ada, karena kedua hal tsersebut saling mempengaruhi satu sama lain. Karena itu, akibat dari kebijakan keraton dan prilaku masyarakat pada kawasan ini dapat berpengaruh kepada elemen fisik spasial pada kawasan ini sendiri.

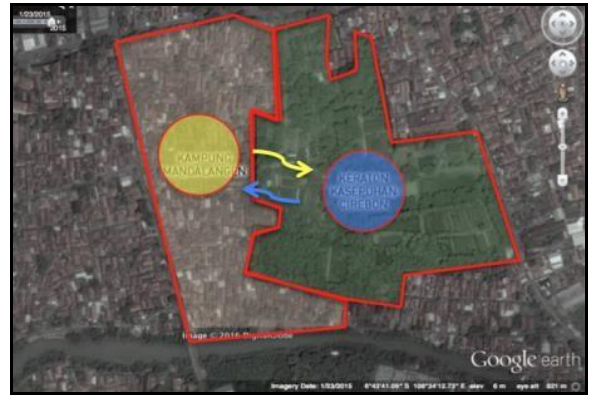

Figur 2. Relasi antar komplek (Sumber: Citra Google Earth diolah pribadi)

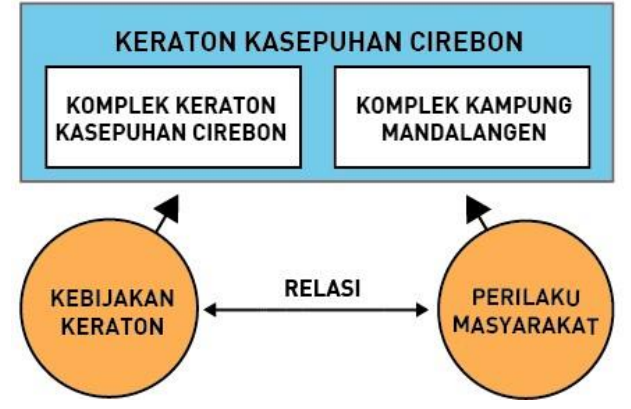

Figur 3. Fakta Non-Fisik Spasial (Sumber: Olahan Pribadi) 


\subsubsection{PERTANYAAN PENELITIAN}

(1) Seperti apa bentuk tautan struktur sirkulasi pada masing-masing komplek di Keraton Kasepuhan Cirebon?

a. Dimana saja letak titik tembus antar atau keluar komplek di Keraton Kasepuhan Cirebon?

b. Dimana letak Backbone / Datum Internal pada masing-masing komplek di Keraton Kasepuhan Cirebon?

(2) Bagaimana orientasi masing-masing komplek terhadap satu sama lain atau dengan Kawasan Keraton Kasepuhan Cirebon?

(3) Bagaimana relasi struktur tautan sirkulasi antar komplek pada Keraton Kasepuhan Cirebon?

\subsubsection{KERANGKA PIKIR}

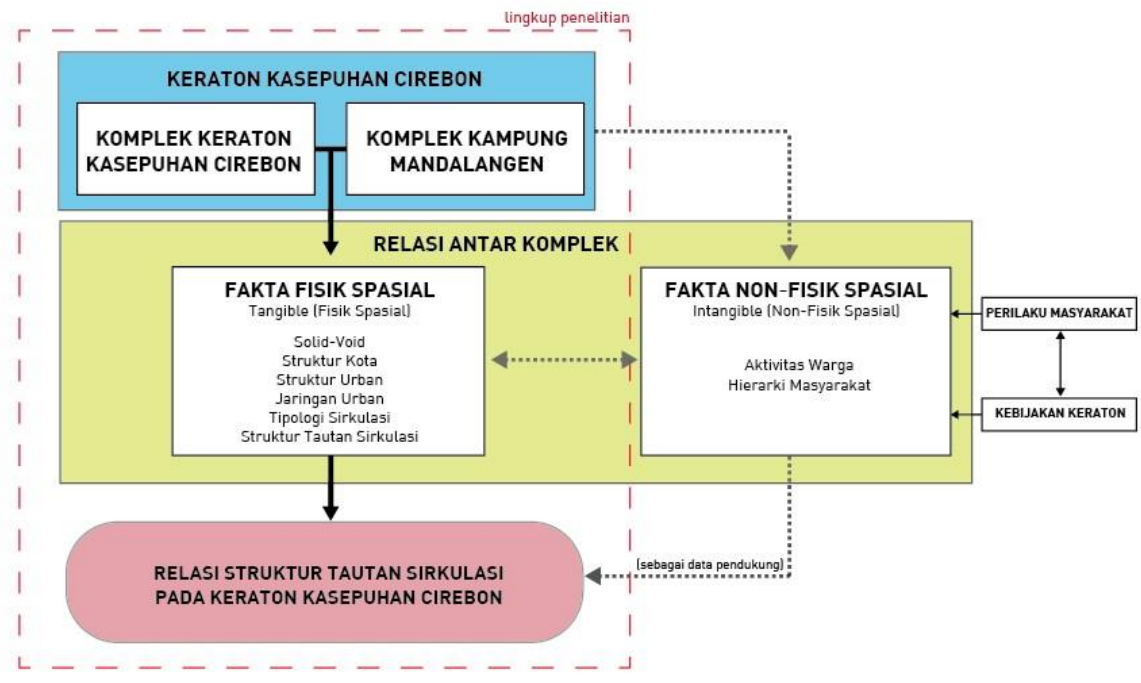

Figur 4. Tembok Benteng pada Keraton Kasepuhan Cirebon (Sumber: Citra Google Earth 2016 diolah pribadi, Dokumentasi Pribadi) 


\subsubsection{LINGKUP PENELITIAN}

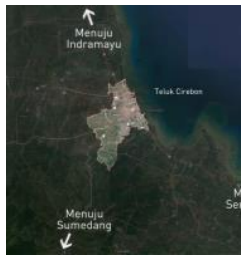

Figur 5. Kota Cirebon dan Relasi Sekitarnya (Sumber: Google Earth, Olahan Pribadi)

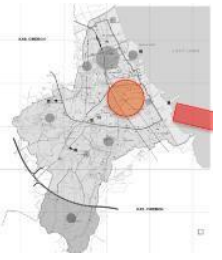

Figur 6. Batas Kawasan Keraton Kasepuhan Cirebon

(Sumber: Bappeda dan

Purnama, Iwan, 2016)

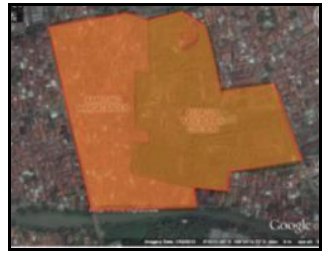

Figur 7. Batas Keraton Kasepuhan Cirebon iumber: Google Earth, Olahan Pribadi)

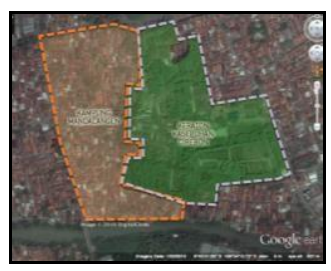

Figur 8. Batas Komplek pada Keraton (Sumber: Google Earth, Olahan Pribadi)

\section{KAJIAN TEORI}

\subsection{KOTA SEBAGAI ARTEFAK (ROSSI, ALDO. 1983)}

Dalam pemahaman dari Aldo Rossi (1982: 86), terdapat tiga urban function dari suatu kota yaitu adalah Housing, Fixed Activities, dan Circulation. Perlu dipahami bahwa maksud dari urban function diatas adalah dimana Housing dan Fixed Activities yang berupa elemen primer pada kota pasti selalu terikat dan terkoneksi dengan sirkulasi diantaranya. Ketiga elemen diatas tidak dapat dihilangkan satu sama lain dan tidak dapat berdiri tanpa salah satunya.

Monumen juga hadir sebagai katalis perkembangan kota (Rossi, 1982). Hal ini dikarenakan monumen menjadi sesuatu yang spesial karena secara bentuk memiliki nilai yang lebih tinggi dari nilai ekonomi dan fungsi (Rossi, 1982). Terlebih, suatu monumen tidak dapat di-duplikasikan ke kota lain dan tidak semua kota memiliki monumen. Karena itu, monumen / landmark menjadi suatu state of the art dari kota itu sendiri.

Perkembangan kota dari titik awal, dari elemen primer (Fixed Activities) lalu Housing (Rossi, 1982). Dimana elemen primer dapat menjadi suatu embrio kota yang menjadi katalis bagi lingkungan sekitar untuk dihuni karena memiliki nilai ekonomi dan nilai fungsi yang beriringan karenanya.

\subsection{FIGURE-GROUND THEORY (TRANCIK, ROGER. 1986)}

Pemahaman pola perkotaa melalui hubungan antara bentuk terbangun (mass) dan ruang terbuka (void). Untuk Identifikasi Tekstur dan pola-pola ruang perkotaan. 


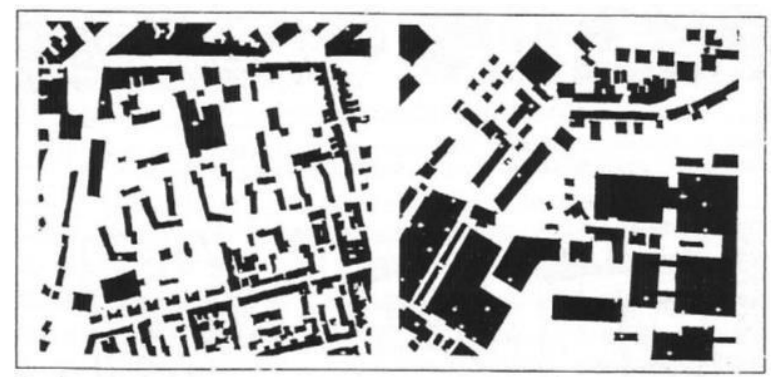

Figur 9. Figure-Ground Theory

(Sumber: Trancik, digambar ulang oleh Zhand, 1999.)

\subsection{STREET PATTERN (MARSHALL, STEPHEN. 2004)}

\subsubsection{COMPOSITION}

Komposisi (Composition) adalah suatu cara untuk melihat suatu pandangan dua dimensional pada sirkulasi akwasan dengan melihat bentuk absolut dari layout geometrinya, sebagaimana direpresentasikan pada sebuah bidang berskala, yang menunjukan lokasi, panjang, area, dan orientasi seutuhnya.

\subsubsection{CONFIGURATION}

Konfigurasi (Configuration) adalah cara melihat suatu sirkulasi dalam bentuk topologi sebagaimana direpresentasikan dalam suatu diagram abstrak yang menunjukan simpul, penghubung (sirkulasi) diantaranya, tatanan, kedekatan, dan konektivitas.

Dalam suatu konfigurasi, dapat dihitung beberapa rasio, yaitu adalah T-Ratio (Ratio simpang yang menghubungkan tiga sirkulasi), dan X-Ratio (Ratio simpang yang menghubungkan empat sirkulasi). Ada juga Cell-Ratio (rasio ruang sel yang tertutup oleh sirkulasi) dengan CulRatio (Ratio jumlah Cul-De-Sac).

\subsubsection{CONSTITUTION}

Constitution (konstitusi) berfokus pada hierarki dari sirkulasi yang ada pada kawasan itu sendiri. Adanya tingkatan-tingkatan yang dibentuk dari intensitas penggunaan sirkulasi. Dari hal tersebut, dapat terlihat suatu "Backbone" dari tautan sirkulasi kawasan.

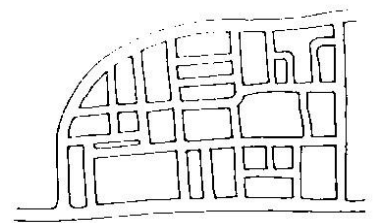

Figur 10. Composition (Sumber: Marshall, 2004)

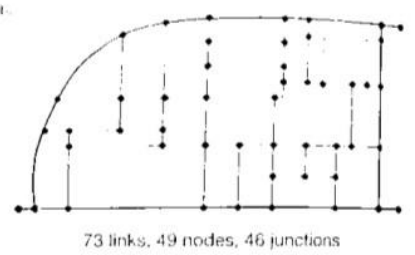

Figur 11. Configuration (Sumber: Marshall, 2004)

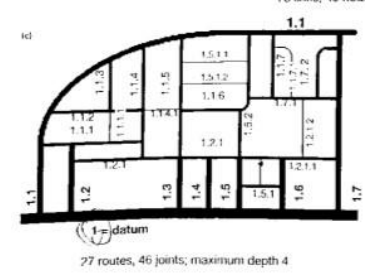

Figur 12. Constution (Sumber: Marshall, 2004) 


\subsubsection{STREET TYPOLOGY}

Constitution (konstitusi) berfokus pada hierarki dari sirkulasi yang ada pada kawasan itu sendiri. Adanya tingkatan-tingkatan yang dibentuk dari intensitas penggunaan sirkulasi. Dari hal tersebut, dapat terlihat suatu "Backbone" dari tautan sirkulasi kawasan.

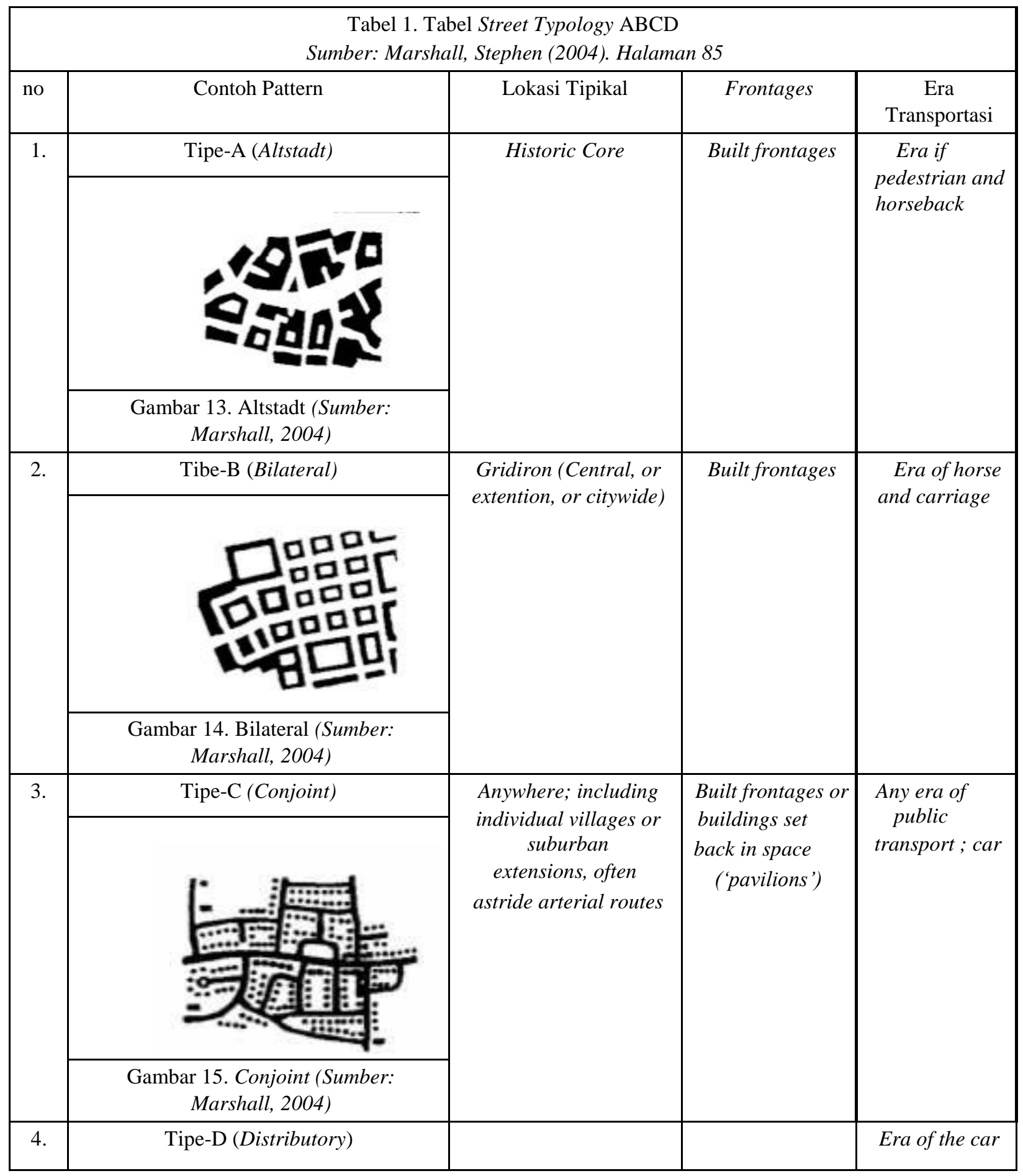




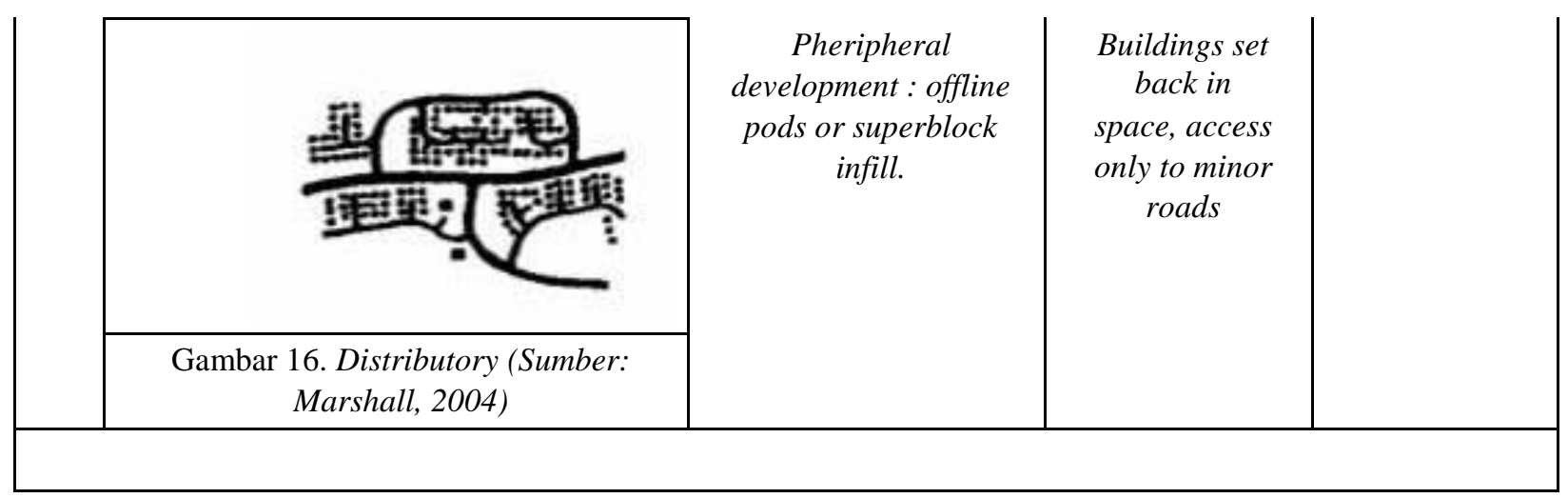

\subsection{KERANGKA TEORITIK}

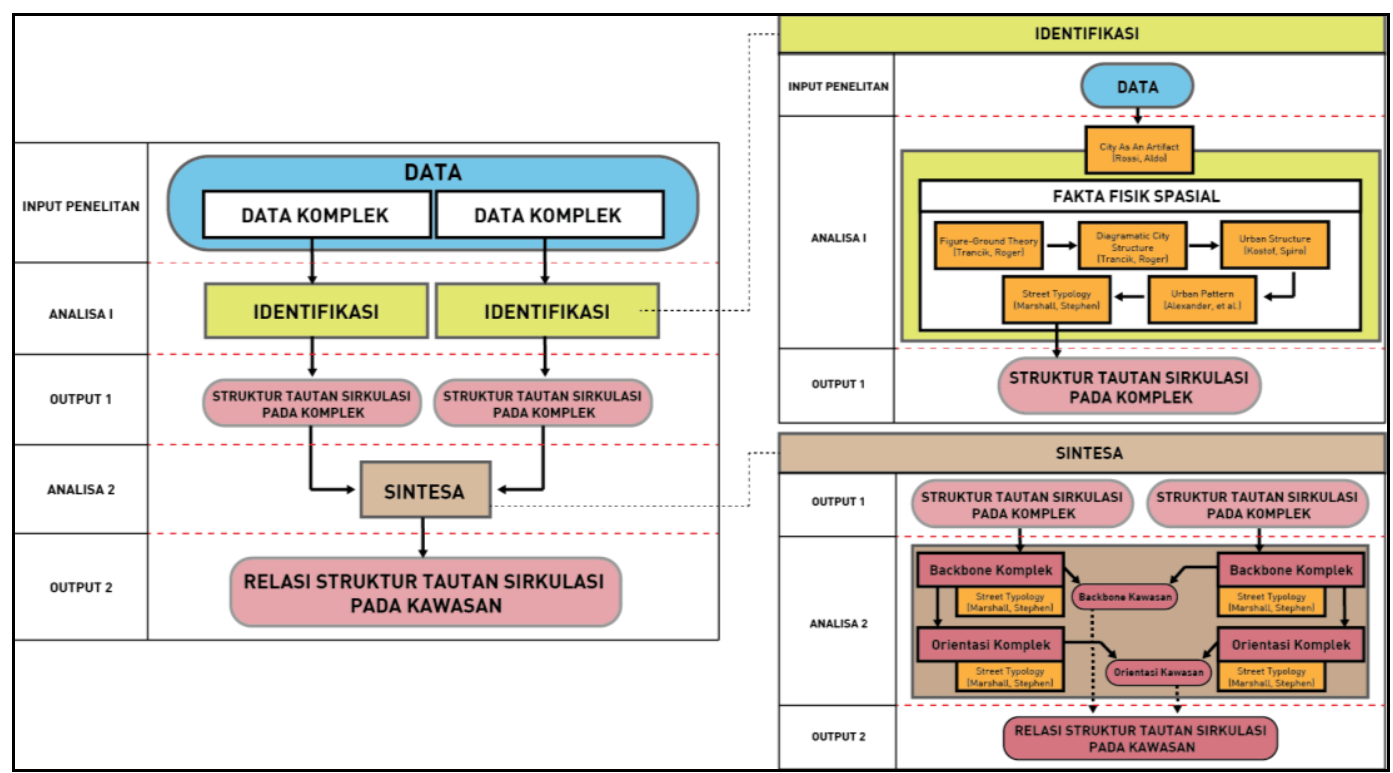

Gambar 17. Kerangka Teoritik

(Sumber: Dokumentasi Pribadi)

\subsection{METODOLOGI PENELITIAN}

\subsubsection{JENIS PENELITIAN}

Jenis penelitian yang ada adalah penelitian Kuantitatif-Deskriptif Linear dengan cara untuk memahami perubahan tautan sirkulasi yang ada pada kawasan tersebut. Kuantitatif adalah dengan mengetahui nilai Continuity, Connectivity, dan Depth, Deskriptif dilaksanakan dengan memahami orientasi kawasan berdasarkan Backbone kawasan yang telah didapatkan dari analisa Continuity, Connectivity, dan Depth sebelumnya.

\subsubsection{TEMPAT DAN WAKTU PENELITIAN}

Penelitian dilakukan pada kawasan lingkup Keraton Kasepuhan Cirebon, Jawa Barat. Penelitian sendiri dilaksanakan pada masa semester gasal tahun ajaran 2016/2017 UNPAR. 
Pengambilan data dilaksanakan pada bulan September - Desember 2016. Telah dilaksanakan 3 kali observasi lapangan pada tanggal 1 September, 17 September, dan 15 Oktober.

\subsubsection{TEKNIK PENGUMPULAN DATA}

Pengambilan data primer dengan melakukan wawancara secara langsung kepada narasumber, menggunakan GIS (geographic information system) dan GPS (Global Positioning System) tracking untuk pemetaan sirkulasi dengan perangkat gawai.

Pengambilan data sekunder dengan melakukan studi pustaka melalui literatur, unduh internet selektif menggunakan data yang terpercaya, data dokumentasi dan studi penelitian bpk. Iwan Purnama.

\subsubsection{KERANGKA PENELITIAN}

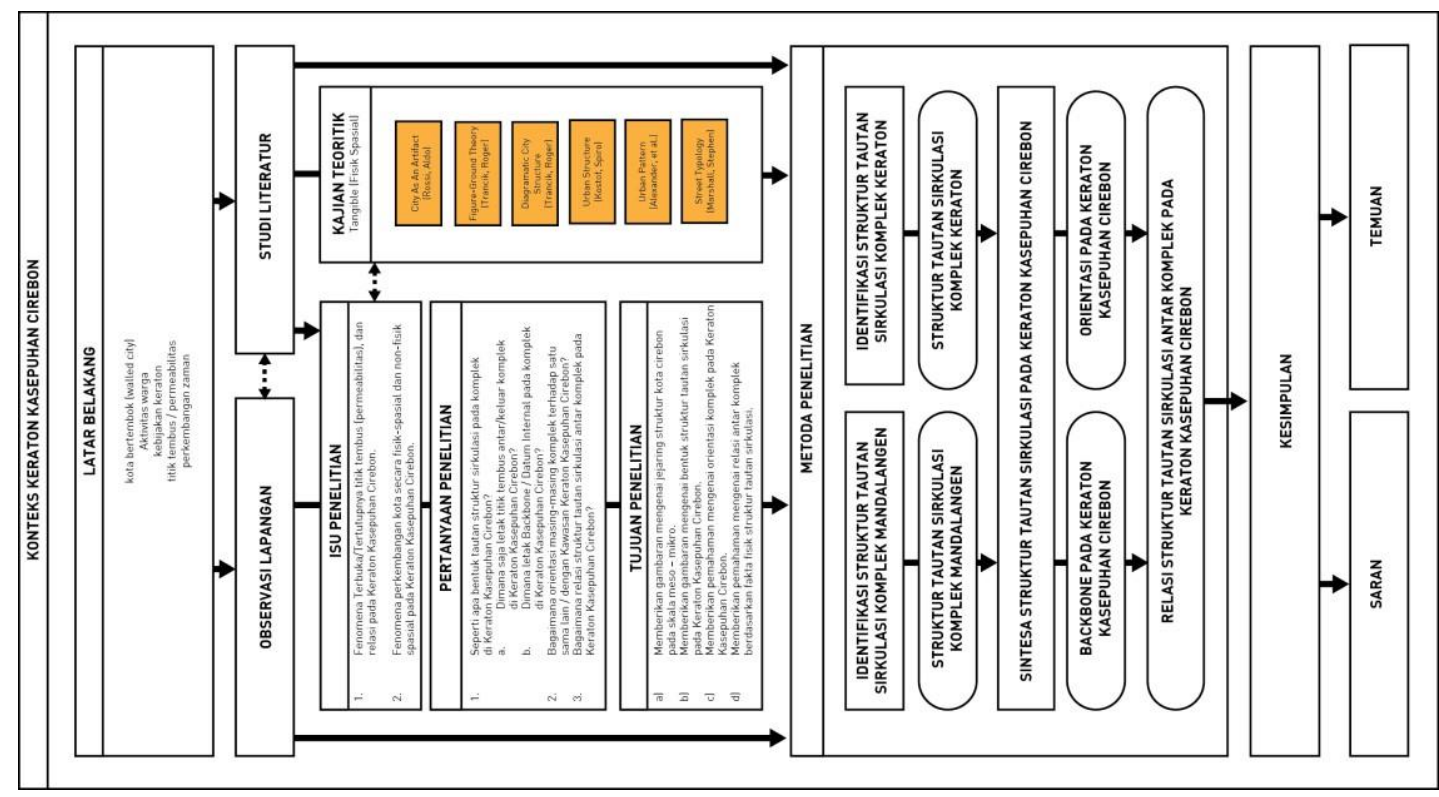

Gambar 18. Kerangka Penelitian

(Sumber: Dokumentasi Pribadi)

\section{ANALISA}

\subsection{IDENTIFIKASI STRUKTUR TAUTAN SIRKULASI PADA KERATON} KASEPUHAN CIREBON

\subsubsection{KOMPLEK KERATON}

\section{Analisa Figure-Ground Theory}

Dalam memahami konteks komplek keraton, diperlukan pemahaman mengenai solidvoid pada komplek ini. Susunan dan konfigurasi yang didapatkan pada tahap ini akan digunakan dalam tahapan analisa selanjutnya. 


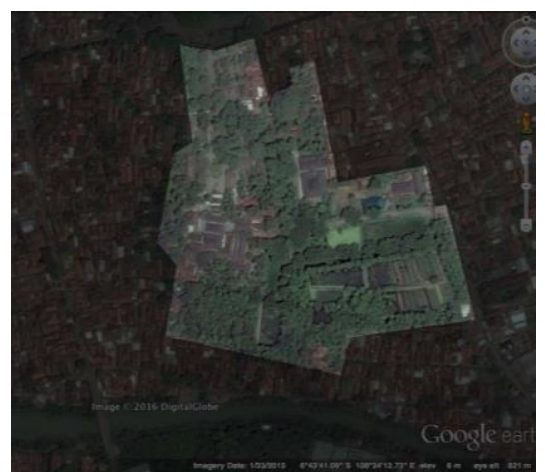

Gambar 19. Citra Komplek Keraton (Sumber: Google Earth, Olahan Pribadi)

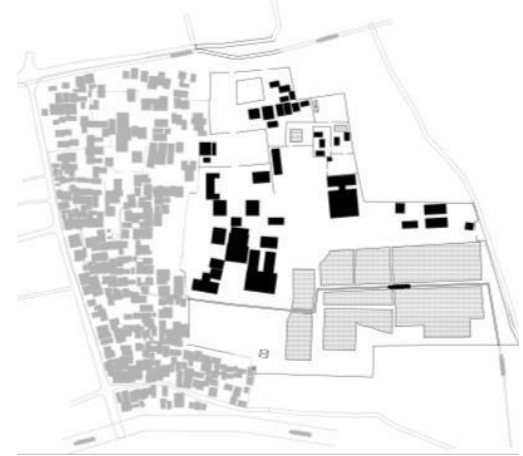

Gambar 20. Solid-void Komplek Keraton (Sumber: Olahan Pribadi)

\section{Analisa Pola Struktur Kota}

Adanya kecenderungan dari pola struktur kota yang ada pada komplek Keraton Kasepuhan Cirebon untuk memiliki suatu bentuk yang berbentuk aksial-organis karena bangunan pada komplek dalam kondisi bermassa tunggal, namun tetap memiliki kecenderungan radial-konsentris. Adanya pemusatan / empasis / penekanan pada ruang-ruang pada bagian utara dan selatan di komplek tersebut.

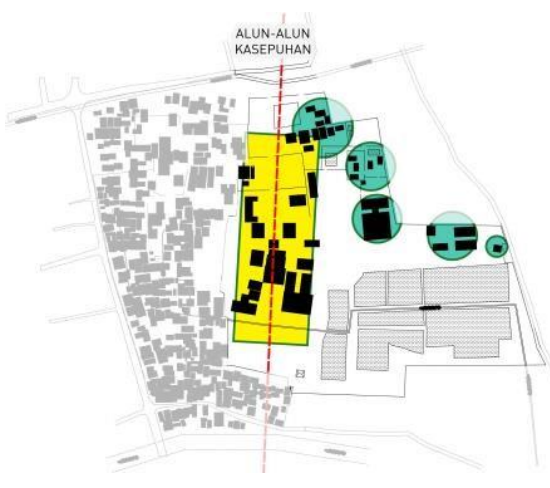

Gambar 21. Pola Struktur Kota Aksial-Organis (Sumber: Olahan Pribadi)

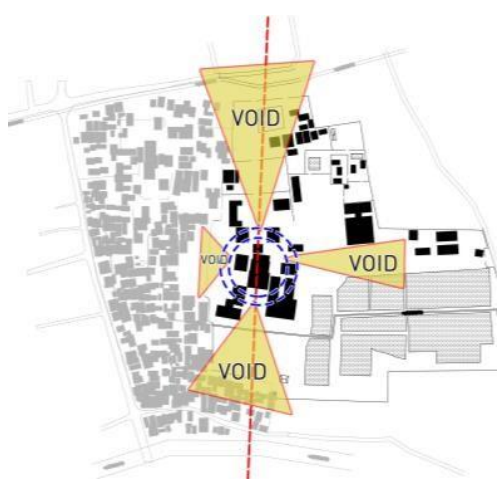

Gambar 22. Pola Struktur Kota Konsentrik (Sumber: Olahan Pribadi)

\section{Analisa Urban Structure}

Dalam komplek keraton ini, karena adanya suatu tingkatan hierarkis dan berdiri sebagai tempat tinggal dari Sultan Sepuh; maka dari komplek ini urban strcture secara diagramatis dengan penekanan hierarkis sistem sosial dipusat komplek tersebut. Adanya regimatisasi yang terlihat dengan adanya jarak yang diberikan antara rumah penduduk, dengan tempat tinggal sultan pada komplek. 


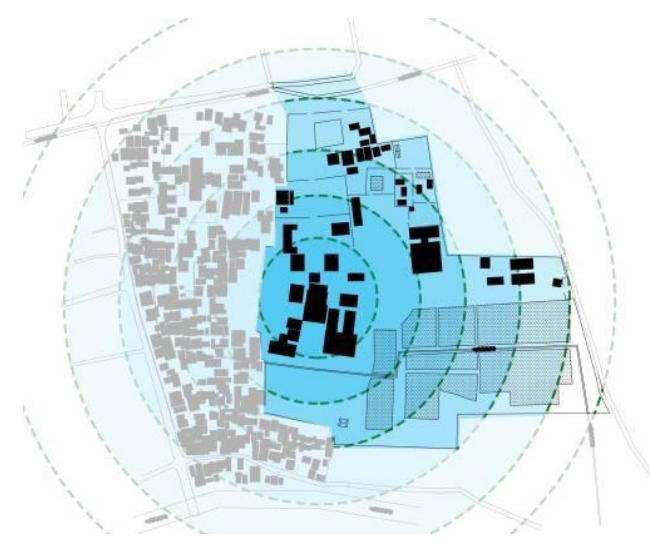

Gambar 23. Urban Structure Diagram Hierarkis

(Sumber : Dokumentasi Pribadi)

\section{Analisa Street Pattern}

\section{(1) Composition}

Komposisi (Composition) adalah suatu cara untuk melihat suatu pandangan dua dimensional pada sirkulasi akwasan dengan melihat bentuk absolut dari layout geometrinya, sebagaimana direpresentasikan pada sebuah bidang berskala, yang menunjukan lokasi, panjang, area, dan orientasi seutuhnya.

Menggunakan analisa dari Figure-Ground Theory, dan data dari pemahaman Urban Structure dan Urban Pattern, dengan memahami bagian void pada kawasan, lalu dilanjutkan dengan mengetahui Composition pada komplek Keraton Kasepuhan Cirebon.

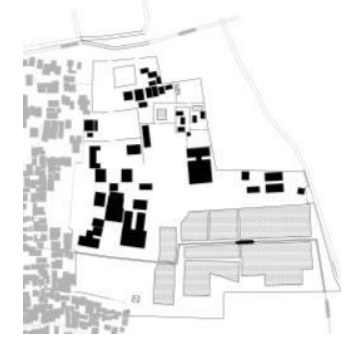

Gambar 24. Solid-void Komplek Keraton (Sumber: Olahan Pribadi)

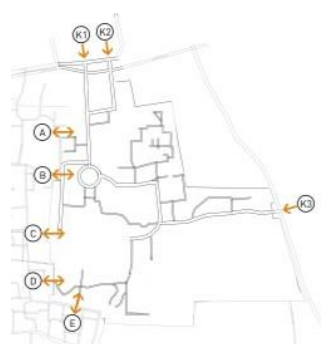

Gambar 25. Composition Komplek Keraton (Sumber: Olahan Pribadi)

\section{Configuration}

Setelah dilakukan analisa secara Composition untuk mengetahui Jaringan Sirkulasi pada Komplek Keraton, lalu dilakukan Analisa Configuration. Datum yang digunakan pada kawasan ini adalah Jalan Kasepuhan yang terletak pada bagian Utara dan Timur dari Komplek Keraton. Didapatkan Nilai Continuity, Connectivity, dan Depth. 


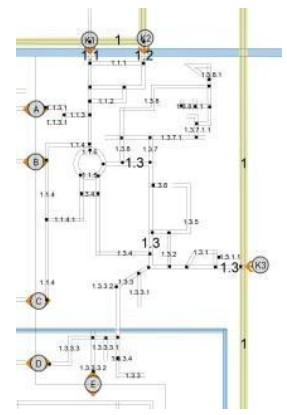

Gambar 26. Configuration Komplek Keraton

(Sumber: Dokumentasi Pribadi)

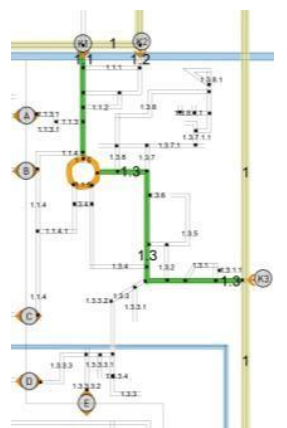

Gambar 27. Datum Internal Komplek Keraton

(Sumber: Dokumentasi Pribadi)

\begin{tabular}{|c|c|c|c|c|c|c|c|c|c|c|c|c|c|}
\hline \multicolumn{14}{|c|}{ CCD KERATON } \\
\hline NO & ROUTE & ENTRANCE? & CONTINUITY & CONNECTIVITY & DEPTH & ROUTE TYPE & No & ROUTE & ENTRANCE? & CONTINUITY & CONNECTIVITY & DEPTH & ROUTE TYPE \\
\hline 1 & 1 & DATUM & DATUM & DATUM & 1 & DATUM & 17 & 1.3 .8 & & 2 & 3 & 3 & \\
\hline 2 & 1.1 & K1 & 6 & 7 & 2 & Stem & 18 & 1.1.3.1 & & 1 & 1 & 4 & \\
\hline 3 & 1.2 & K2 & 3 & 4 & 2 & & 19 & 1.1.4.1 & & 2 & 3 & 4 & \\
\hline 4 & 1.3 & K3 & 10 & 11 & 2 & Stem & 20 & 1.3.1.1 & A & 1 & 2 & 4 & \\
\hline 5 & 1.1 .1 & & 1 & 2 & 3 & & 21 & 1.3.3.1 & & 1 & 1 & 4 & \\
\hline 6 & 1.1.2 & & 1 & 2 & 3 & & 22 & 1.3.3.2 & & 1 & 1 & 4 & \\
\hline 7 & 1.1 .3 & & 1 & 2 & 3 & & 23 & 1.3.3.3 & $D$ & 3 & 4 & 4 & \\
\hline 8 & 1.1 .4 & $\mathrm{~B} / \mathrm{C}$ & 4 & 4 & 3 & & 24 & 1.3.3.4 & & 1 & 1 & 4 & \\
\hline 9 & 1.1.5 & & 4 & 4 & 3 & Cross-connector & 25 & 1.3.4.1 & & 1 & 2 & 4 & \\
\hline 10 & 1.3 .1 & & 2 & 3 & 3 & & 26 & 1.3.7.1 & & 4 & 3 & 4 & \\
\hline 11 & 1.3 .2 & & 1 & 2 & 3 & & 27 & 1.3 .8 .1 & & 1 & 1 & 4 & \\
\hline 12 & 1.3 .3 & & 5 & 5 & 3 & & 28 & 1.3.3.3.1. & & 1 & 1 & 5 & \\
\hline 13 & 1.3 .4 & & 2 & 3 & 3 & & 29 & 1.3.3.3.2. & $E$ & 2 & 2 & 5 & \\
\hline 14 & 1.3 .5 & & 2 & 2 & 3 & & 30 & 1.3.7.1.1 & & 2 & 2 & 5 & \\
\hline 15 & 1.3 .6 & & 1 & 1 & 3 & & 31 & 1.3.8.1.1. & & 3 & 3 & 5 & \\
\hline 16 & 1.3 .7 & & 1 & 2 & 3 & & & TOT & $\mathrm{AL}$ & 70 & 84 & 105 & \\
\hline
\end{tabular}

Gambar 28. Analisa CCD Komplek Keraton

(Sumber: Dokumentasi Pribadi)

Route type

Dari hasil observasi dan nilai Continuity, dan Connectvity. Terdapat fakta bahwa rute 1.1. dan 1.3 memiliki nilai yang cukup signifikan dibandingkan dengan rute-rute lainnya. Dari hasil analisa route type, didapatkan bahwa kedua rute tersebut adalah dalam tipe "Stem". Rute 1.1.5 juga memiliki tipe Trans-Connector karena menjadi penghubung antara kedua Backbone di Komplek Keraton.

Tabel 2. Tabel Street Types

Sumber: Marshall, Stephen (2004). Halaman 124.

\begin{tabular}{|c|c|c|c|}
\hline \multicolumn{2}{|c|}{ Tipe Rute } & Deskripsi Struktural & $\begin{array}{c}\text { Peran tipikal rute pada } \\
\text { jaringan }\end{array}$ \\
\hline no & Stem & $\begin{array}{c}\text { Persimpangan berbentuk } \\
\text { simpang- } \\
\text { tiga }\end{array}$ & $\begin{array}{c}\text { Beragam, termasuk } \\
\text { distribusi } \\
\text { konvensional pada jaringan }\end{array}$ \\
\cline { 2 - 2 } & $\begin{array}{c}\text { Gambar 29. Stem (Sumber: Marshall, } \\
\text { 2004) }\end{array}$ & & \\
\hline
\end{tabular}




\begin{tabular}{|c|c|c|c|}
\hline \multirow{2}{*}{2.} & Cross-connector & $\begin{array}{c}\text { Sebuah rute pendek yang } \\
\text { karena nilai } \\
\text { Depth dan relativ } \\
\text { disContinuity-nya } \\
\text { memiliki nilai yang } \\
\end{array}$ & $\begin{array}{c}\text { Ditemukan diinterior dari } \\
\text { jaringan grid }\end{array}$ \\
\cline { 2 - 2 } & tinggi dari relatif \\
& Connectivitynya & \\
\hline
\end{tabular}

\section{Constitution}

Berdasarkan nilai Depth yang ada, didapatkan Constution. Dapat dilihat bahwa Backbone pada komplek memang sangat berperan sebagai penghubung pada sirkulasi sekunder dan tersier pada komplek. Adanya aterialitas yang menghubungkan dari utara hingga selatan tanpa konstrain.

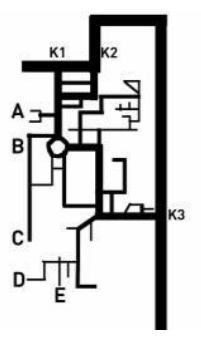

Gambar 31. Constitution Komplek Keraton

(Sumber : Dokumentasi Pribadi)

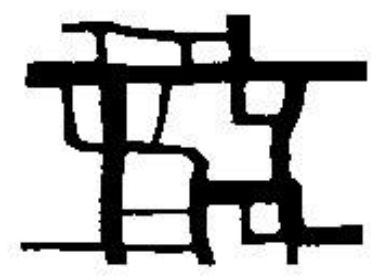

Gambar 32. Tipe Constitution Conjoint (Sumber : Marshall, 2004)

\section{Street Typology}

Menggunakan hasil dari analisa Configuration pada Komplek Keraton, dapat dicari nilai T-X Ratio dan Cell-Cul Ratio untuk mengetahui Street Typology pada Komplek Keraton. Rasio yang digunakan lalu dikomparasikan dengan contoh yang ada pada landasan teoritik.

Tabel 3. Tabel Nilai T-X Ratio dan Cell-Cull Ratio Komplek Keraton

Sumber: Marshall, Stephen (2004). Halaman 99

\begin{tabular}{|c|c|c|c|c|c|}
\hline \multicolumn{3}{|c|}{ T-X Ratio } & \multicolumn{3}{c|}{ Cell-Cull Ratio } \\
\hline T-Ratio & 46 & $\mathbf{0 , 9 6}$ & Cell-Ratio & 12 & $\mathbf{0 , 5 5}$ \\
\hline X-Ratio & 2 & $\mathbf{0 , 0 4}$ & Cul-Ratio & 10 & $\mathbf{0 , 4 5}$ \\
\hline & 48 & 1,00 & & 22 & 1,00 \\
\hline
\end{tabular}

Dari data diatas, diidentifikasi bahwa jenis Street Typology pada Komplek keraton ini adalah tipe altstadt (a-type) 
Tabel 4. Tabel Street Typology ABCD

Sumber : Marshall, Stephen (2004). Halaman 85.

\begin{tabular}{|c|c|c|c|c|}
\hline no & Contoh Pattern & Lokasi Tipikal & Frontages & Era Transportasi \\
\hline \multirow[t]{3}{*}{1.} & Tipe-A (Altstadt) & \multirow[t]{3}{*}{ Historic Core } & \multirow[t]{3}{*}{ Built frontages } & \multirow{3}{*}{$\begin{array}{c}\text { Era if pedestrian } \\
\text { and horseback }\end{array}$} \\
\hline & & & & \\
\hline & $\begin{array}{c}\text { Gambar 33. Altstadt (Sumber: } \\
\text { Marshall, 2004) }\end{array}$ & & & \\
\hline
\end{tabular}

\subsubsection{KOMPLEK MANDALANGEN}

\section{Analisa Figure-Ground Theory}

Dalam memahami konteks komplek mandalangen, diperlukan pemahaman mengenai solidvoid pada komplek ini. Susunan dan konfigurasi yang didapatkan pada tahap ini akan digunakan dalam tahapan analisa selanjutnya

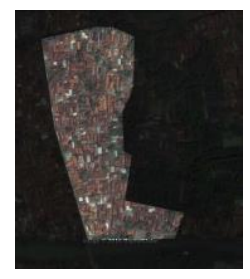

Gambar 34. Citra Komplek Mandalangen

(Sumber : Google Earth)

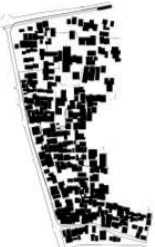

Gambar 35. SolidVoid Komp. Mandalangen (Sumber : Dokumentasi Pribadi)

\section{Analisa Pola Struktur Kota}

Adanya kecenderungan pola struktur kota yang ada pada komplek Kampung Mandalangen untuk memiliki suatu bentuk yang berwujud organis. Adanya void tertentu yang menjadikan kluster massa menjadi renggang dan padat. Pada bagian utara, terlihat bahwa bangunan cukup renggang dan memiliki banyak ruang antara pada bagian tersebut. Semakin ke arah selatan, ruangruang tersebut semakin hilang dan kepadatanpun meningkat.

\section{Analisa Urban Structure}

Dalam hasil analisa scara Urban Structure, rterlihat bahwanya ada tendensi untuk menjadi tatanan grid tidak sempurna pada komplek kampung mandalangen, bentuk organik, secara sporadis juga muncul, namun tetap memiliki koridor sirkulasi yang jelas dan bersudut siku-siku (90 derajat) 


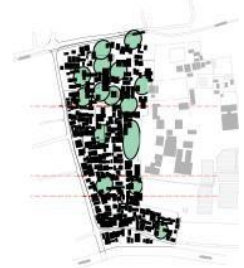

Gambar 36. Void pada Komplek Mandalangen (Sumber: Olahan Pribadi)

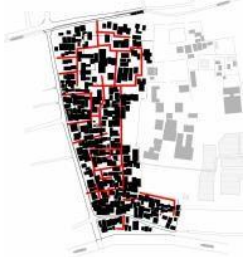

Gambar 37. Urban Structure Komplek Mandalangen (Sumber: Olahan Pribadi)

\section{Analisa Street Pattern}

(1) Composition

Menggunakan analisa dari Figure-Ground Theory, dan data dari pemahaman Urban Structure dan Urban Pattern, dengan memahami bagian void pada kawasan, lalu dilanjutkan dengan mengetahui Composition pada komplek Keraton Kasepuhan Cirebon.

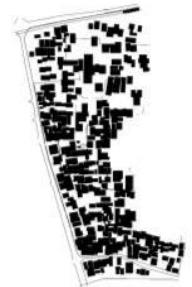

Gambar 38. Solid-void Komplek Mandalangen

(Sumber : Dokumentasi Pribadi)

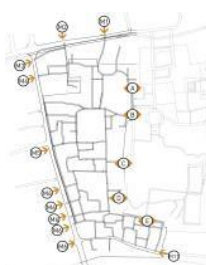

Gambar 39. Composition Komplek Mandalangen

(Sumber: Dokumentasi Pribadi)

\section{Configuration}

Setelah dilakukan analisa secara Composition untuk mengetahui Jaringan Sirkulasi pada Komplek Kampung Mandalangen, lalu dilakukan Analisa Configuration. Datum yang digunakan pada kawasan ini adalah Jalan Pegajahan yang terletak pada bagian Utara dan Barat dari Komplek Kampung Mandalangen. Didapatkan Nilai Continuity, Connectivity, dan Depth dari hasil analisa ini. 


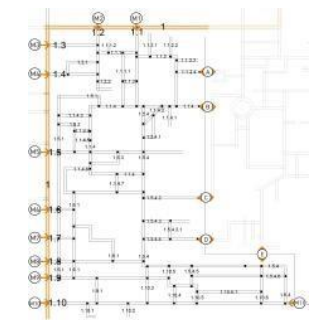

Gambar 40. Configuration Komplek Mandalangen (Sumber: Dokumentasi Pribadi)

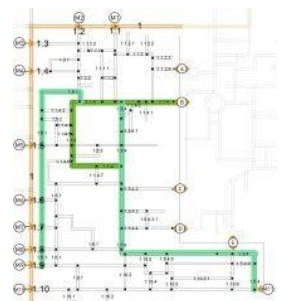

Gambar 41. Datum Internal Komplek Mandalangen (Sumber: Dokumentasi Pribadi)

\begin{tabular}{|c|c|c|c|c|c|c|c|c|c|c|c|c|c|}
\hline \multicolumn{14}{|c|}{ CCD MANDALANGEN } \\
\hline No & ROUTE & ENTRANCE? & CONTINUITY & CONNECTIVITY & DEPTH & ROUTE TYPE & No & ROUTE & ENTRANCE? & CONTINUITY & CONNECTIVITY & DEPTH & ROUTE TYPE \\
\hline 1 & 1 & DATUM & DATUM & DATUM & 1 & DATUM & 27 & 1.10 .3 & & 1 & 2 & 3 & \\
\hline 2 & 1.1 & M1 & 4 & 5 & 2 & & 28 & 1.10 .4 & & 1 & 2 & 3 & \\
\hline 3 & 1.2 & M2 & 6 & 6 & 2 & & 29 & 1.10 .5 & & 5 & 6 & 3 & Collector \\
\hline 4 & 1.3 & M3 & 1 & 2 & 2 & & 30 & 1.10 .6 & & 3 & 4 & 3 & \\
\hline 5 & 1.4 & M4 & 2 & 3 & 2 & & 31 & 1.1.1.1 & & 2 & 3 & 4 & \\
\hline 6 & 1.5 & M5 & 6 & 6 & 2 & Collector & 32 & 1.1 .1 .2 & & 1 & 1 & 4 & \\
\hline 7 & 1.6 & M6 & 2 & 3 & 2 & & 33 & 1.1.2.1 & & 1 & 1 & 4 & \\
\hline 8 & 1.7 & M7 & 2 & 3 & 2 & & 34 & 1.1 .2 .2 & & 1 & 1 & 4 & \\
\hline 9 & 1.8 & M8 & 4 & 5 & 2 & & 35 & 1.1 .2 .3 & & 1 & 1 & 4 & \\
\hline 10 & 1.9 & M9 & 5 & 6 & 2 & Collector & 36 & 1.1 .2 .4 & A & 1 & 2 & 4 & \\
\hline 11 & 1.10 & M10/M11 & 9 & 9 & 3 & Collector & 37 & 1.1.4.1 & & 1 & 1 & 4 & \\
\hline 12 & 1.1.1 & & 3 & 4 & 3 & & 38 & 1.1 .4 .2 & & 2 & 3 & 4 & \\
\hline 13 & 1.1.2 & & 5 & 6 & 3 & & 39 & 1.1 .4 .3 & & 1 & 2 & 4 & \\
\hline 14 & 1.1.3 & . & 1 & 2 & 3 & & 40 & 1.1 .4 .4 & & 1 & 2 & 4 & \\
\hline 15 & 1.1 .4 & B & 15 & 16 & 3 & Stem & 41 & 1.1 .4 .5 & & 1 & 1 & 4 & \\
\hline 16 & 1.2 .1 & & 1 & 2 & 3 & & 42 & 1.1 .4 .6 & & 3 & 4 & 4 & \\
\hline 17 & 1.2 .2 & & 1 & 1 & 3 & & 43 & 11.1 .4 .7 & & 1 & 2 & 4 & \\
\hline 18 & 1.5.1 & & 7 & 8 & 3 & Spine & 44 & \begin{tabular}{|l|}
1.5 .4 .1 \\
\end{tabular} & & 1 & 2 & 4 & \\
\hline 19 & 1.5 .2 & & 2 & 3 & 3 & & 45 & \begin{tabular}{|l|l}
1.5 .4 .2 \\
\end{tabular} & c & 1 & 2 & 4 & \\
\hline 20 & 1.5 .3 & & 1 & 2 & 3 & & 46 & 1.5 .4 .3 & & 1 & 1 & 4 & \\
\hline 21 & 1.5 .4 & E & 16 & 17 & 3 & Stem & 47 & 1.5 .4 .4 & D & 2 & 3 & 4 & \\
\hline 22 & 1.6 .1 & & 5 & 6 & 3 & & 48 & 1.5 .4 .5 & & 2 & 3 & 4 & \\
\hline 23 & 1.8 .1 & & 1 & 2 & 3 & & 49 & 1.5 .4 .6 & & 2 & 3 & 4 & \\
\hline 24 & 1.9 .1 & & 1 & 2 & 3 & & 50 & 11.10 .5 .1 & & 1 & 2 & 4 & \\
\hline 25 & 1.10 .1 & & 1 & 1 & 3 & & 51 & \begin{tabular}{|l}
1.5 .4 .3 .1 \\
\end{tabular} & & 1 & 2 & 5 & \\
\hline & & & & & & & & & & 38 & 56 & 97 & \\
\hline
\end{tabular}

Gambar 42. Analisa CCD Komplek Mandalangen (Sumber:

Dokumentasi Pribadi)

\section{Route type}

Dari hasil observasi dan nilai Continuity, dan Connectivity. Terdapat fakta bahwa rute 1.1.4, 1.5.1, dan 1.5.4 memiliki nilai yang cukup signifikan dibandingkan dengan rute-rute lainnya. Dari hasil analisa route type, didapatkan bahwa ketiga rute tersebut adalah dalam tipe "Stem dan Spine". Rute 1.5.1 bersifat spine karena persimpangannya memiliki lebih banyak cabang 4 dibanding kedua Backbone lainnya di Komplek ini.

Tabel 5.

Sumber: Marshall, Stephen (2004). Halaman 124

\begin{tabular}{|c|c|c|c|}
\hline no & Tipe Rute & Deskripsi Struktural & $\begin{array}{l}\text { Peran tipikal rute pada } \\
\text { jaringan }\end{array}$ \\
\hline \multirow[t]{2}{*}{1.} & Stem & \multirow{2}{*}{$\begin{array}{l}\text { Persimpangan berbentuk } \\
\text { simpang- } \\
\text { tiga }\end{array}$} & \multirow{2}{*}{$\begin{array}{c}\text { Beragam, termasuk } \\
\text { distribusi } \\
\text { konvensional pada jaringan }\end{array}$} \\
\hline & Lلـ & & \\
\hline
\end{tabular}




\begin{tabular}{|c|c|c|c|}
\hline & $\begin{array}{c}\text { Gambar 43. Stem (Sumber: Marshall, } \\
\text { 2004) }\end{array}$ & & \\
\hline \multirow[t]{3}{*}{2.} & Spine & \multirow{3}{*}{$\begin{array}{l}\text { Persimpangan berbentuk } \\
\text { simpangempat }\end{array}$} & \multirow{3}{*}{$\begin{array}{l}\text { Tradisional konektif pada } \\
\text { jaringan grid }\end{array}$} \\
\hline & 1 & & \\
\hline & $\begin{array}{c}\text { Gambar 44. Spine (Sumber: Marshall, } \\
\text { 2004) }\end{array}$ & & \\
\hline
\end{tabular}

\section{Constitution}

Berdasarkan nilai Depth yang ada, didapatkan Constution. Dapat dilihat bahwa Backbone pada komplek memang sangat berperan sebagai penghubung pada sirkulasi sekunder dan tersier pada komplek. Adanya aterialitas yang menghubungkan dari utara hingga selatan tanpa konstrain

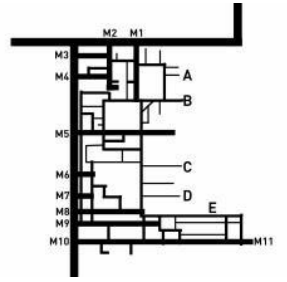

Gambar 45. Constitution Komplek Keraton

(Sumber : Dokumentasi Pribadi)

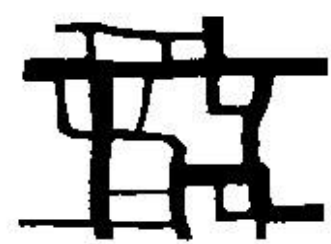

Gambar 46. Tipe Constitution Conjoint

(Sumber : Marshall, 2004)

\section{Street Typology}

Menggunakan hasil dari analisa Configuration pada Komplek Keraton, dapat dicari nilai T-X Ratio dan Cell-Cul Ratio untuk mengetahui Street Typology pada Komplek Keraton. Rasio yang digunakan lalu dikomparasikan dengan contoh yang ada pada landasan teoritik.

Tabel 6. Tabel Nilai T-X Ratio dan Cell-Cull Ratio Komplek Mandalangen

Sumber: Marshall, Stephen (2004). Halaman 99

\begin{tabular}{|c|c|c|c|c|c|}
\hline \multicolumn{3}{|c|}{ T-X Ratio } & \multicolumn{3}{c|}{ Cell-Cull Ratio } \\
\hline T-Ratio & 80 & $\mathbf{0 , 8 8}$ & Cell-Ratio & 44 & $\mathbf{0 , 8 0}$ \\
\hline X-Ratio & 11 & $\mathbf{0 , 1 2}$ & Cul-Ratio & 14 & $\mathbf{0 , 2 0}$ \\
\hline & 91 & 1,00 & & 55 & 1,00 \\
\hline & & & \\
\hline
\end{tabular}

Dari data diatas, diidentifikasi bahwa jenis Street Typology pada Komplek Kampung Mandalangen ini adalah tipe Conjoint (c-type)

Tabel 7. Tabel Street Typology ABCD 
Sumber: Marshall, Stephen (2004). Halaman 85

\begin{tabular}{|c|c|c|c|c|}
\hline no & Contoh Pattern & Lokasi Tipikal & Frontages & Era Transportasi \\
\hline \multirow{3}{*}{3.} & Tipe-C (Conjoint) & \multirow{3}{*}{$\begin{array}{l}\text { Anywhere; including } \\
\text { individual } \\
\text { villages or suburban } \\
\text { extensions, } \\
\text { often astride arterial } \\
\text { routes }\end{array}$} & \multirow{3}{*}{$\begin{array}{l}\text { Built frontages or } \\
\text { buildings set } \\
\text { back in space } \\
\text { ('pavilions') }\end{array}$} & \multirow{3}{*}{$\begin{array}{c}\text { Any era of public } \\
\text { transport ; car }\end{array}$} \\
\hline & 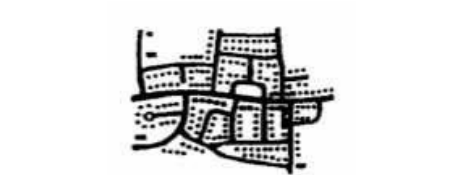 & & & \\
\hline & $\begin{array}{c}\text { Gambar 47. Conjoint (Sumber: } \\
\text { Marshall, 2004) }\end{array}$ & & & \\
\hline
\end{tabular}

\section{$\begin{array}{llll}3.2 & \text { SINTESA } & \text { STRUKTUR TAUTAN } & \text { SIRKULASI PADA }\end{array}$ KASEPUHAN CIREBON \\ 3.2.1 SINTESA BACKBONE}

Dari data output identifkasi kedua komplek yang telah ada, lalu dilaksanakan sintesa secaara tahapan Configuration untuk menggabungkan Backbone keduanya. Yang diperhitungkan sebagai Backbone adalah Street Types berupa Stem, Spine, dan Crossconnector.

Kehadiran tipe Trans-Connector pada rute 1.1.5 juga memberikan pandangan bahwa untuk menghubungkan kedua "stem" yang ada pada komplek ini sangat bergantung dengan rute 1.1.5 diatas. Disana, terlihat signifikansi dari bentuk Trans-Connector tersebut sebagai satu-satunya bentuk lingkaran, tidak hanya pada komplek keraton, namun pada seluruh kawasan ini.

Sementara itu, dengan fakta data dari Backbone komplek kampung mandalangen, rute 1.1.4 memiliki "penetrasi" langsung berupa pengakhiran dengan titik tembus antar komplek, yaitu titik tembus B. Rute 1.5.4 juga memiliki koneksi dengan titik tembus E pada bagian selatan komplek, namun titik tembus itu hanya bersinggungan dan berupa persimpangan dari pintu yang tidak digunakan lagi.

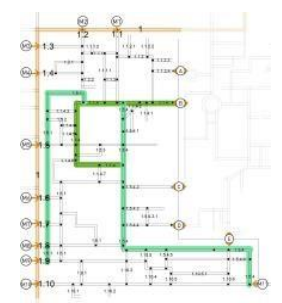

Gambar 48. Datum Internal Komp. Mandalangen

(Sumber: Dokumentasi Pribadi)

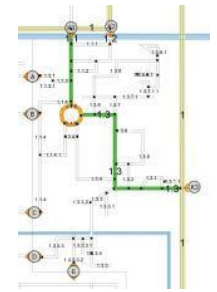

Gambar 49. Datum Internal Komp. Keraton (Sumber: Dokumentasi Pribadi)

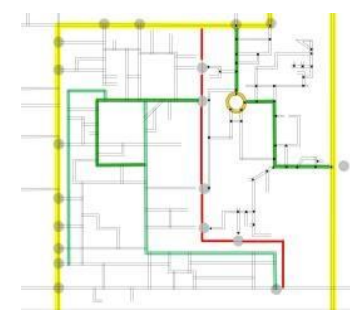

Gambar 50. Datum Internal Keraton Kasepuhan Cirebon (Sumber: Dokumentasi Pribadi) 


\subsubsection{SINTESA ORIENTASI}

Setelah mendapatkan Backbone pada masing-masing komplek di Keraton Kasepuhan Cirebon, lalu akan dilanjutkan dengan menentukan orientasi dari komplek tersebut. Beberapa hal yang menentukan orientasi adalah "frontage" Backbone dari komplek tersebut.

Pada komplek Keraton Kasepuhan Cirebon, terdapat adanya orientasi yang jelas dari frontage yang ada pada komplek tersebut. Sesuai dengan analisa sebelumnya mengenai pola diagamatik kota dan Urban Structure pada komplek ini yang memiliki kencenderungan hierarkis menghadap ke istana/tempat tinggal sultan itu sendiri.

Namun, sebelum dihadapkan secara langsung ke tempat tinggal sultan, akses dari frontage kedua rute datum internal (rute 1.1 dan 1.3) dihadapkan dengan simpul yang berupa jenis rute cross-connector (rute 1.1.5). Sehingga, terjadi suatu pertemuan yang saling mengikat dan menghubungkan rute, sebelum dihadapkan ke tempat tinggal sultan.

Pada komplek kampung mandalangen, terdapat dua jenis frontage, yaitu frontage langsung seperti yang telah ada sebelumnya, dan frontage tidak langsung. Dalam hal ini, rute 1.5.1 tidak memiliki akses langsung ke titik tembus M5-M9, namun terdapat rute 1.5, 1.6, 1.7, 1.8, dan 1.9 yang hanya memiliki perbedaan derajat Depth 1.

Adanya orientasi yang menghadap ke frontage titik tembus B yang dihadapkan oleh rute 1.1.4, yang menjadi datum internal pada komplek. Disaat yang sama, rute 1.5.1 dan 1.5.4 bergabung menuju ke rute 1.1.4 sebelum menuju ke titik tembus B.

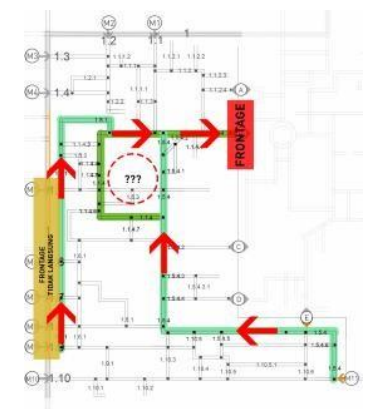

Gambar 48. Frontage Komp. Mandalangen

(Sumber: Dokumentasi Pribadi)

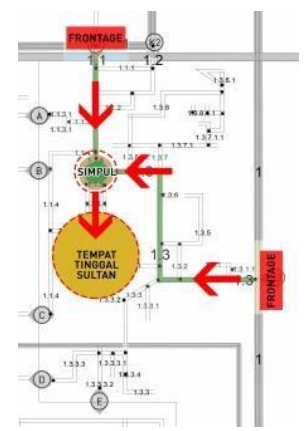

Gambar 49. Frontage Komp. Keraton

(Sumber: Dokumentasi Pribadi)

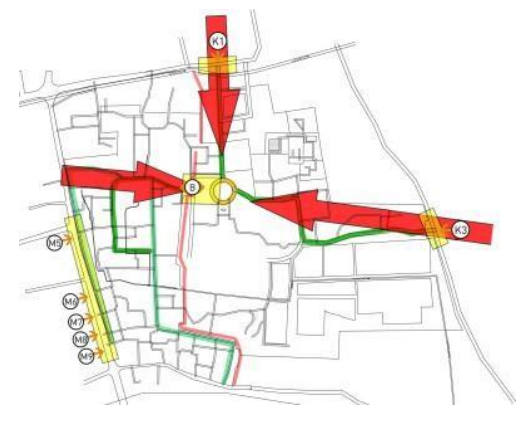

Gambar 50. Orientasi Keraton Kasepuhan Cirebon (Sumber: Dokumentasi Pribadi)

\subsection{JAWABAN PERTANYAAN PENELITIAN}

Seperti apa bentuk tautan struktur sirkulasi pada masing-masing komplek di Keraton Kasepuhan Cirebon?

Pada komplek Keraton Kasepuhan Cirebon, memiliki tipologi sirkulasi tipe A (Altstadt) dengan jenis struktur konstitusi tipe Conjoint. Pada komplek Kampung Mandalangen, memiliki tipologi sirkulasi tipe $\mathrm{C}$ (Conjoint) dengan jenis struktur konstitusi tipe Conjoint.

Dimana saja letak titik tembus antar/keluar komplek di Keraton Kasepuhan Cirebon?

Terdapat 3 jenis titik tembus pada Keraton Kasepuhan Cirebon:

Titik Tembus Antar Komplek (5 Titik, A-E) 
Titik Tembus Keluar Komplek Keraton (3 Titik, K1-K3)

Titik Tembus Keluar Komplek Mandalangen (11 Titik, (M1-M11)

\section{Dimana letak Backbone / Datum Internal pada masing-masing komplek di Keraton Kasepuhan Cirebon?}

Pada komplek Keraton Kasepuhan Cirebon, terdapat datum internal yang terdiri dari tiga segmen, yaitu rute 1.1, 1.1.5 dan 1.3. Pada komplek kampung mandalangen terdapat datum internal utama rute 1.1.4. dan sekunder rute 1.5.1 dan 1.5.4.

\section{Bagaimana orientasi masing-masing komplek terhadap satu sama lain / dengan Kawasan Keraton Kasepuhan Cirebon?}

Pada komplek Keraton Kasepuhan Cirebon memiliki orientasi hierarkis ke tempat tinggal sultan, namun sebelumnya mengarah ke simpul utama di bagian utara dari tempat tersebut. Pada komplek kampung mandalangen memiliki orientasi menuju ke titik tembus B, yaitu frontage dari datum internal utama pada komplek tersebut. Apabila dilihat secara bersamaan, bahwa pada kedua komplek cenderung memiliki orientasi menghadap ke titik simpul utama pada bagian komplek Keraton Kasepuhan Cirebon, yaitu bundaran Dewandanu.

\section{Cirebon?}

Bagaimana relasi tautan struktur sirkulasi antar komplek pada Keraton Kasepuhan

Ditemukan adanya diskontinuitas struktur tautan sirkulasi pada kawasan yang terjadi pada lingkaran dibawah, adanya dua fenomena yang terjadi: (1) Fenomena tertutupnya titik tembus B secara publik

Adanya kebijakan dari pihak keraton untuk menutup sirkulasi pada titik tembus B, secara publik. Hal ini mengakibatkan sirkulasi publik antar komplek harus melewati titik tembus lainnya yang masih terbuka (titik tembus A dan D).

Tabel 8. Pintu Titik tembus B

\begin{tabular}{|l|c|l|}
\hline B. & $\begin{array}{l}\text { Pada titik tembus B, digunakan sebagai sirkulasi bagi kerabat } \\
\text { keraton pada kawasan untuk pintu masuk mobil. }\end{array}$ \\
\hline & $\begin{array}{c}\text { Gambar 51. Orientasi Keraton } \\
\text { Kasepuhan Cirebon }\end{array}$ & \\
\hline
\end{tabular}

(2) Fenomena adanya bangunan museum benda kuno yang menutup dan menuntut pencapaian yang diputar pada jalur sirkulasi tersebut. 
Terdapat bangunan berupa museum bangunan kuno yang menghalangi akses langsung untuk menuju ke bundaran dewandanu, bangunan ini mengharuskan pencapaian berupa pencapaian yang diputar untuk bangunan ini.

Tabel 9. Bangunan Museum Benda Kuno

\begin{tabular}{|l|l|l}
\hline 6. & $\begin{array}{l}\text { Museum benda kuno berdungsi untuk } \\
\text { menyimpan barang-barang antik peninggalan } \\
\text { sejarah seperti kerajinan dalam dan luar } \\
\text { negeri, alat upacara adat, dan juga senjata } \\
\text { sebagai koleksi. }\end{array}$ \\
Gambar 52. Museum Benda Kuno (Sumber: Google & Streetview)
\end{tabular}

\subsection{TEMUAN}

\subsubsection{KEDUA KOMPLEK MEMILIKI STREET TYPOLOGY YANG BERBEDA}

Ditemukan adanya perbedaan tipologi ada di kedua komplek ini. Hal ini mendandakan, meskipun kemungkinan bahwa lingkungan, yaitu Housing dan Fixed Activities ini dibentuk pada saat yang sama. Ini memandakan bahwa adanya perubahan dari komplek kampung mandalangen yang lebih dinamis mengikuti perkembangan zaman. Pada saat yang sama, lingkungan komplek keraton sebagai suatu lingkungan yang lebih privat dan sakral menjadi lebih kuat dan bertahan dari perubahan jaman dan memegang identitasnya sendiri

\subsubsection{ORIENTASI KAMPUNG MANDALANGEN MASIH MENGHADAP KE KERATON}

Dari orientasi kompolek kampung mandalangen, masih terlihat bahwa komplek ini memiliki kecenderungan menghadap ke arah Keraton Kasepuhan Cirebon, namun pada saat yang sama juga seiring perkembangan zaman. adanya aktivitas yang lebih beragam mengakibatkan diperlukan tembusan-tembusan baru menuju ke luar-komplek, bukan antar komplek. 


\subsubsection{TITIK TITIK TEMBUS PADA KAMPUNG MANDALANGEN TIDAK TERIKAT DENGAN BACKBONE, TANDA DIBENTUK SETELAHNYA}

Fakta fisik spasial secara datum internal masih mengisyaratkan orientasi ke keraton, namun secara aktivitas, tembusan-tembusan baru menunjukan perkembangan aktivitas komplek tidak hanya menuju ke keraton, tapi juga keluar keraton.

\subsubsection{PENUTUPAN TITIK TEMBUS B SEBAGAI KEBIJAKAN DARI KERATON. KARENA TERBUKA EKSKLUSIF}

Adanya kebijakan dari pihak keraton untuk menutup sirkulasi pada titik tembus B, secara publik. Hal ini mengakibatkan sirkulasi publik antar komplek harus melewati titik tembus lainnya yang masih terbuka (titik tembus A dan D). Meskipun secara hierarki sirkulasi sangat terlihat signifikansi dari pintu ini, tetapi kondisi saat ini membuat pintu ini tidak bisa digunakan secara publik, sehingga memutus tautan sirkulasi yang ada diantara kedua komplek pada Keraton Kasepuhan Cirebon ini.

\subsubsection{BANGUNAN MUSEUM BENDA KUNO MEMILIKI FUNGSI PENTING SEBELUM MENJADI MUSEUM}

Tentunya, karena bangunan ini menghalangi akses secara visual dan fisik dari titik tembus $\mathrm{B}$, kemungkinan besar bangunan ini fungsi terdahulunya bukan museum, namun memiliki fungsi pembatas antara kedua belah komplek. Sehingga, ada dua kemungkinan, dimana apakah bangunan ini berfungsi sebagai pembatas pada dahulunya, atau baru dibangun namun melupkan signifikansi dari datum internal kampung mandalangen ini.

\section{KESIMPULAN}

\subsection{KESIMPULAN}

Kesimpulan dari penulisan ini adalah:

(1) Diidentifkasi kesamaan orientasi struktur tautan sirkulasi datum internal dari kedua komplek yang menghadap kearah simpul bundaran dewandaru. (2) Diidentfikasi dua pemutus hubungan sirkulasi diantara kedua komplek tersebut yaitu adalah:

a. ditutupnya akses publik titik tembus B, sebagai titik kontinu penghubung datum internal kampung mandalangen menuju ke bundaran dewanaru

b. terdapat bangunan museum benda kuno sebagai penghalang visual dan fisik dari akses datum internal kampung mandalangen menuju ke bundaran dewandaru

sehingga, dapat disimpulkan bahwa terjadi diskontinuitas struktur tautan sirkulasi antar komplek (komplek Keraton Kasepuhan Cirebon dan komplek kampung mandalangen) pada Keraton Kasepuhan Cirebon.

\subsection{SARAN}

Saran dari penulisan ini adalah:

(1) perlunya bagi penulis selanjutnya mengenai pemahaman mengenai fakta non-fisik spasial, hal yaitu: 
a. pemahaman mengenai kebijakan keraton mengenai faktor-faktor mengapa terjadi penutupan secara publik pada titik tembus B

b. pemahaman mengenai historis kebijakan pembangunan atau fungsi sebelumnya dari museum benda kuno mengenai relasi dan kepentingannya antara komplek kampung mandalangen dan komplek Keraton Kasepuhan Cirebon

c. pemahaman mengenai signifikansi aktivitas warga diantara kedua belah komplek, untuk memperhatikan "dialog" aktivitas yang tersisa diantara kedua belah komplek.

(2) Perlunya peninjauan mengenai signifikansi titik-titik tembus lainnya (titik A,C,D,E) untuk bisa mengetahui secara historis tujuan dan fungsi dari kehadiran pintu-pintu tersebut.

\section{DAFTAR PUSTAKA}

Bacon, Edmund. (1978). Design of Cities. New York: Penguin Books.

Hasan, Yudoko (2004). Kajian elemen fisik dan alkukturasi budaya pada arsitektur keraton Cirebon: objek studi Keraton Kasepuhan dan Keraton Kanoman. Bandung. Skripsi: Arsitektur Universitas Katolik Parahyangan.

Kostof, Spiro. (1992). The City Assembled. London: Thames and Hudson.

Krier, Rob (1997). Urban Space. New York: Rizzoli International Publications.

Kusliansjah, Karyadi. Et al. (2012) Struktur Pesisir (Waterfront) Kota Cirebon-Jawa Barat: Studi kasus: Telaah Morfologi Kawasan Pesisir Keluarahan Panjunan, Lemah Wungkuk, Kasepuhan, Kasunean - Kota Cirebon. Bandung: LPPM Universitas Katolik Parahyangan (Perjanjian No. III/LPPM/2012-09/111-P).

Maki, Fumuhiko (1964). Investigations in Collective Form. St. Louis: Washington University Publications.

Marshall, Stephen (2004). Streets and Patterns. London and New York: Spon Press, Taylor, and Francis Group.

McCluskey, Jim. (1979). Roadform and Townscape. London: Architectural Press.

Nugroho, Imam. (2002). Arsitektur Mesjid Agung Kasepuhan Cirebon. Bandung. Skripsi: Arsitektur Universitas Katolik Parahyangan.

Rossi, Aldo. (1984). Architecture of the City. Masaschusets: the MIT Press

Shirvani, Hamid (1985). The Urban Design Process. New York: Van Nostrand Reinhold Company.

Trancik, Roger (1992). Finding Lost Space. Theories in Urban Design. New York: Van Nostrand Reinhold Company.

Zhand, Markus. (1999). Perancangan Kota Secara Terpadu. Jogjakarta: Kanisius 